\title{
Characterisation of Familial Colorectal Cancer Type X, Lynch syndrome, and non-familial colorectal cancer
}

S Shiovitz ${ }^{1,2}$, W K Copeland ${ }^{3}$, M N Passarelli ${ }^{3}$, A N Burnett-Hartman ${ }^{3,4}$, W M Grady 1,2,3 , J D Potter ${ }^{3,4,5}$, S Gallinger ${ }^{6}$, D D Buchanan ${ }^{7,8}$, C Rosty ${ }^{8,9,10}$, A K Win $^{7}, \mathrm{M} \mathrm{Jenkins}^{7}$, S N Thibodeau ${ }^{11}$, R Haile ${ }^{12}$, J A Baron ${ }^{13}$, L L Marchand ${ }^{14}$, P A Newcomb $b^{3,4}$ and N M Lindor ${ }^{15}$ for the Colon Cancer Family Registry

${ }^{1}$ Department of Medicine, University of Washington, Seattle, WA, USA; ${ }^{2}$ Clinical Research Division, Fred Hutchinson Cancer Research Center, Seattle, WA, USA; ${ }^{3}$ Public Health Sciences Division, Fred Hutchinson Cancer Research Center, Seattle, WA, USA; ${ }^{4}$ Department of Epidemiology, University of Washington, Seattle, WA, USA; ${ }^{5}$ Centre for Public Health Research, Massey University, Wellington, New Zealand; ${ }^{6}$ Samuel Lunenfeld Research Institute, Mount Sinai Hospital, Toronto, ON, Canada; ${ }^{7}$ University of Melbourne, Parkville, VIC, Australia; ${ }^{8}$ Cancer and Population Studies Group, Queensland Institute of Medical Research, Brisbane, QLD, Australia; ${ }^{9}$ University of Queensland, School of Medicine, Herston, OLD, Australia; ${ }^{10}$ Envoi Pathology, Herston, OLD, Australia; ${ }^{11}$ Department of Laboratory Medicine and Pathology, Mayo Clinic, Rochester, MN, USA; ${ }^{12}$ Stanford Cancer Institute, Palo Alto, CA, USA; ${ }^{13}$ Department of Medicine, University of North Carolina School of Medicine, Chapel Hill, NC, USA; ${ }^{14}$ University of Hawaii Cancer Center, Honolulu, HI, USA and ${ }^{15}$ Department of Health Science Research, Mayo Clinic, Scottsdale, AZ, USA

Background: Familial Colorectal Cancer Type X (FCCTX) is defined as individuals with colorectal cancer (CRC) who families meet Amsterdam Criteria-1 (AC1), but whose tumours are DNA-mismatch-repair-proficient, unlike Lynch syndrome (LS). FCCTX does not have an increased risk of extra-colonic cancers. This analysis compares epidemiologic and clinicopathologic features among FCCTX, LS, and 'non-familial' (non-AC1) CRC cases.

Methods: From the Colon Cancer Family Registry, FCCTX $(n=173)$, LS $(n=303)$, and non-AC1 $(n=9603)$ CRC cases were identified. Questionnaire-based epidemiologic information and CRC pathologic features were compared across case groups using polytomous logistic regression.

Results: Compared with LS, FCCTX cases were less likely to be current (vs never) smokers; have a proximal subsite (vs rectal) tumour; or have mucinous histology, poor differentiation, or tumour-infiltrating lymphocytes. There were no observed differences in co-morbidities or medication usage.

Conclusions: FCCTX were less likely to be current tobacco users; other exposures were similar between these groups. Histopathologic differences highly suggestive of LS CRCs do not appear to be shared by FCCTX.

'Familial Colorectal Cancer Type X' (FCCTX) collectively describes cases of colorectal cancer (CRC) that meet clinical Amsterdam Criteria-1 (AC1) for Lynch syndrome (LS), but whose tumours are DNA-mismatch-repair-proficient as assessed by tumour immunohistochemistry (IHC) and/or microsatellite instability (MSI) testing
(Vasen et al, 1991; Lindor et al, 2005). Approximately half of CRC cases who meet AC1 (three relatives with CRC across two successive generations (with one case being a first-degree relative of the other two), at least one case diagnosed before age 50, and the exclusion of familial adenomatous polyposis), are now classified as 
FCCTX (Lynch \& de la Chapelle, 2003; Renkonen et al, 2003; Schiemann et al, 2004; Woods et al, 2005). FCCTX pedigrees show an autosomal-dominant inheritance pattern, but the genetic basis remains unknown, and may constitute more than one genetic aetiology.

Previous studies have indicated clinical and pathologic differences between FCCTX and LS (online Supplementary Table S1). Relative to LS, FCCTX is associated with lower predisposition to CRC (standard incidence ratio 2.3 vs 6.1), is not associated with extracolonic cancers (Lindor et al, 2005), has an older mean age at diagnosis (50-60 years vs 40 years), is more likely to be left-sided, and is less likely to be associated with synchronous or metachronous cancers. Histopathologically, FCCTX vs LS CRCs have more heterogeneous architecture, a predominant tubular growth pattern, less frequent mucinous histology, and less often with peritumoural or tumour-infiltrating lymphocytes (TIL) (Schiemann et al, 2004; Lindor et al, 2005; Llor et al, 2005; Mueller-Koch et al, 2005; Dove-Edwin et al, 2006; Valle et al, 2007; Chen et al, 2008; Koh et al, 2011; Klarskov et al, 2012).

To our knowledge, there have been no reports that compare epidemiologic characteristics across FCCTX, LS, and non-Amsterdam Criteria-1 (non-AC1) cases and there are few large studies that describe the breadth of histopathologic features in these groups. Our study aimed to describe the demographic, environmental, and tumour characteristics of FCCTX and determine how they compare with LS and non-AC1 cases within the Colon Cancer Family Registry (CCFR).

\section{MATERIALS AND METHODS}

As described elsewhere (Newcomb et al, 2007), the CCFR (http:// coloncfr.org) is an international consortium of CRC cases and controls from population- and/or clinic-based sites in North America and Australasia. Recruited during 1998-2007, participants completed written informed consent for study enrolment; protocols were approved by local institutional review boards. Collection of epidemiologic and family history data and biospecimens was standardised across all centres.

The following tumour characteristics were abstracted from the clinical histopathology report and/or from pathologist review: location, size, nodal status, differentiation, histologic type, and presence/absence of peritumoural lymphocytes, Crohn's-like reaction, tumour-infiltrating lymphocytes, and venous invasion. MSI and/or IHC were performed on all tumour samples (Lindor et al, 2005; Newcomb et al, 2007).

Cases were allocated to one of the three groups: (1) 'LS' $(n=312)$ for cases meeting $\mathrm{AC} 1$ and whose tumours were classified as MSI (MSI-high and/or MMR-deficient), (2) 'FCCTX' $(n=177)$ for cases meeting AC1, but with non-MSI tumours, or (3) 'non-AC1' $(n=12,175)$ for the remainder of CRC cases whose family histories did not meet AC1. No more than one individual per family was included in the analysis. Restricting the analysis to available epidemiologic/tumour information, we included 173/146 FCCTX, 303/245 LS, and 9603/7878 non-AC1 CRC cases.

Statistical methods. Odds ratios (OR) with 95\% confidence intervals were estimated using polytomous logistic regression

Table 1. Epidemiologic characteristics of FCCTX compared with Lynch syndrome and non-Amsterdam Criteria-1 colorectal cases in the Colon Cancer Family Registry

\begin{tabular}{|c|c|c|c|c|c|c|}
\hline Characteristic, n (\%) & $\begin{array}{c}\text { FCCTX } \\
(n=173)\end{array}$ & $\begin{array}{c}\text { Lynch } \\
(n=303)\end{array}$ & $\begin{array}{l}\text { Non-AC1 } \\
(n=9,603)\end{array}$ & $\begin{array}{l}\text { FCCTX vs Lynch }^{a} \\
\text { OR }^{b}(95 \% \mathrm{Cl})\end{array}$ & $\begin{array}{l}\text { FCCTX vs } \\
\text { non-AC1 } \\
\text { OR }^{\mathrm{b}}(95 \% \mathrm{Cl})\end{array}$ & $\begin{array}{c}\text { Lynch vs non-AC1 } \\
\text { OR }^{\mathrm{b}}(95 \% \mathrm{Cl})\end{array}$ \\
\hline \multicolumn{7}{|l|}{ Case characteristics ${ }^{c}$} \\
\hline Age, mean (s.d.) & $53.3(11.3)$ & 50.5 (11.4) & $56.3(12.0)$ & $1.02(1.00,1.03)$ & $0.99(0.98,1.00)$ & $0.97(0.96,0.98)$ \\
\hline Male gender & $76(44 \%)$ & $149(49 \%)$ & 4797 (50\%) & $0.81(0.56,1.18)$ & $0.80(0.59,1.09)$ & $0.99(0.79,1.25)$ \\
\hline BMI, mean (s.d.) & $27.5(6.6)$ & $26.5(5.8)$ & $27.2(5.8)$ & $1.03(0.10,1.07)$ & $1.02(0.99,1.04)$ & $0.98(0.96,1.01)$ \\
\hline \multicolumn{7}{|l|}{ Smoking } \\
\hline Never & 85 (49\%) & $148(49 \%)$ & $4252(45 \%)$ & 1 (Reference) & 1 (Reference) & 1 (Reference) \\
\hline Former & 74 (43\%) & 106 (35\%) & 4198 (44\%) & $1.17(0.78,1.76)$ & $0.99(0.72,1.37)$ & $0.85(0.65,1.11)$ \\
\hline Current & $13(8 \%)$ & 49 (16\%) & $1096(11 \%)$ & $0.48(0.24,0.94)$ & $0.62(0.35,1.13)$ & $1.30(0.93,1.83)$ \\
\hline \multicolumn{7}{|c|}{ Co-morbidities (yes/no) (\% yes) } \\
\hline Diabetes & 17/155 (9\%) & $20 / 283(7 \%)$ & $1154 / 8404(12 \%)$ & $1.48(0.74,2.94)$ & $1.16(0.69,1.94)$ & $0.78(0.49,1.25)$ \\
\hline Hyperlipidemia & $42 / 129$ (24\%) & $79 / 222(26 \%)$ & $2995 / 6530(31 \%)$ & $0.84(0.53,1.31)$ & $0.88(0.61,1.27)$ & $1.05(0.80,1.39)$ \\
\hline Aspirin & $38 / 134(22 \%)$ & $68 / 231(22 \%)$ & $2771 / 6747$ (29\%) & $0.83(0.52,1.34)$ & $0.99(0.68,1.46)$ & $1.19(0.89,1.60)$ \\
\hline Acetaminophen & $23 / 149$ (13\%) & $51 / 250(17 \%)$ & $1469 / 8026(15 \%)$ & $0.72(0.42,1.23)$ & $0.81(0.52,1.27)$ & $1.13(0.83,1.55)$ \\
\hline NSAIDs & $31 / 141$ (18\%) & $53 / 249$ (17\%) & $1555 / 7910(16 \%)$ & $1.01(0.62,1.66)$ & $1.16(0.78,1.73)$ & $1.14(0.84,1.56)$ \\
\hline Laxatives & $39 / 133$ (23\%) & $60 / 242$ (20\%) & $2136 / 7375$ (22\%) & $1.04(0.65,1.65)$ & $1.04(0.72,1.51)$ & $1.01(0.75,1.36)$ \\
\hline Multivitamin & 73/99 (42\%) & $131 / 171(43 \%)$ & 4829/4702 (50\%) & $0.88(0.60,1.31)$ & $0.98(0.71,1.34)$ & $1.10(0.86,1.41)$ \\
\hline Folic acid & $22 / 150(13 \%)$ & $39 / 261$ (13\%) & $941 / 8528(10 \%)$ & $1.03(0.58,1.84)$ & $1.13(0.70,1.80)$ & $1.09(0.76,1.57)$ \\
\hline Calcium & $36 / 136$ (21\%) & $59 / 244(19 \%)$ & $2507 / 7012$ (26\%) & $0.84(0.51,1.38)$ & $0.80(0.54,1.19)$ & $0.95(0.70,1.30)$ \\
\hline \multicolumn{7}{|l|}{ Female (yes/no) (\% yes) } \\
\hline Oral hormonal contraceptives & 70/27 (72\%) & $115 / 39(75 \%)$ & $2783 / 1972(58 \%)$ & $0.93(0.50,1.72)$ & $1.31(0.81,2.12)$ & $1.41(0.95,2.09)$ \\
\hline PMH with uterus intact & $23 / 41(36 \%)$ & $48 / 67(41 \%)$ & $1041 / 1805(36 \%)$ & $0.44(0.05,3.92)$ & $0.90(0.12,6.80)$ & $2.04(0.76,5.42)$ \\
\hline PMH with hysterectomy & $6 / 12(33 \%)$ & $12 / 26(32 \%)$ & $314 / 471$ (39\%) & $0.68(0.35,1.34)$ & $1.19(0.68,2.09)$ & $1.76(1.17,2.64)$ \\
\hline \multicolumn{7}{|c|}{ 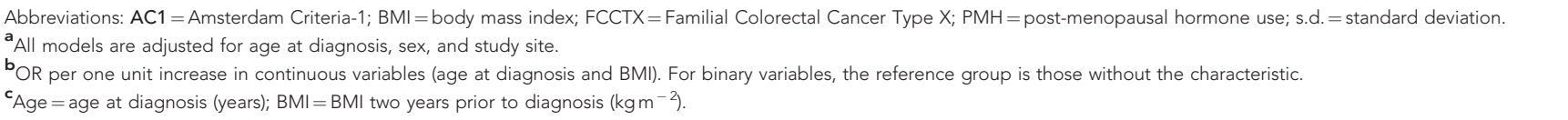 } \\
\hline
\end{tabular}


Table 2. Histopathologic characteristics of FCCTX in CCFR compared with Lynch syndrome and non-Amsterdam Criteria-1 colorectal cases

\begin{tabular}{|c|c|c|c|c|c|c|}
\hline $\begin{array}{l}\text { Characteristic, } \\
\text { n (\%) }\end{array}$ & $\begin{array}{c}\text { FCCTX } \\
(n=146)\end{array}$ & $\begin{array}{l}\text { Lynch } \\
(n=245)\end{array}$ & $\begin{array}{c}\text { Non-AC1 } \\
(n=7,878)\end{array}$ & $\begin{array}{l}\text { FCCTX vs Lynch }^{a} \\
\text { OR }(95 \% \mathrm{Cl})\end{array}$ & $\begin{array}{c}\text { FCCTX vs non- } \\
\text { AC1 } 1^{\mathrm{a}} \\
\text { OR }(95 \% \mathrm{Cl})\end{array}$ & $\begin{array}{c}\text { Lynch vs non-AC1 }{ }^{\text {a }} \\
\text { OR }(95 \% \mathrm{Cl})\end{array}$ \\
\hline \multicolumn{7}{|l|}{ Cancer subsite } \\
\hline $\begin{array}{l}\text { Caecum } \\
\text { Ascending } \\
\text { Transverse } \\
\text { Descending } \\
\text { Sigmoid } \\
\text { Rectum } \\
\text { Missing/other }\end{array}$ & $\begin{array}{c}17(12 \%) \\
15(10 \%) \\
13(9 \%) \\
7(5 \%) \\
37(25 \%) \\
50(34 \%) \\
7(5 \%)\end{array}$ & $\begin{array}{l}55(22 \%) \\
64(26 \%) \\
31(13 \%) \\
14(6 \%) \\
22(9 \%) \\
37(15 \%) \\
22(9 \%)\end{array}$ & $\begin{array}{c}1034(13 \%) \\
1129(14 \%) \\
578(7 \%) \\
438(6 \%) \\
1931(25 \%) \\
2455(31 \%) \\
313(4 \%)\end{array}$ & $\begin{array}{c}0.18(0.09,0.37) \\
0.13(0.06,0.27) \\
0.27(0.12,0.59) \\
0.38(0.14,1.08) \\
1.02(0.51,2.04) \\
1 \text { (Reference) }\end{array}$ & $\begin{array}{c}0.95(0.54,1.67) \\
0.66(0.35,1.22) \\
1.18(0.63,2.21) \\
0.78(0.35,1.74) \\
0.98(0.63,1.52) \\
1 \text { (Reference) }\end{array}$ & $\begin{array}{c}5.2(3.32,8.14) \\
5.22(3.37,8.07) \\
4.44(2.67,7.41) \\
2.03(1.03,3.99) \\
0.96(0.55,1.66) \\
1 \text { (Reference) }\end{array}$ \\
\hline \multicolumn{7}{|l|}{ T-stage } \\
\hline $\begin{array}{l}\text { T1 } \\
\text { T2 } \\
\text { T3 } \\
\text { T4 } \\
\text { Missing }\end{array}$ & $\begin{array}{l}22(15 \%) \\
26(18 \%) \\
74(51 \%) \\
11(8 \%) \\
13(8 \%)\end{array}$ & $\begin{array}{c}27(11 \%) \\
48(20 \%) \\
127(52 \%) \\
9(4 \%) \\
34(13 \%)\end{array}$ & $\begin{array}{r}958(12 \%) \\
1328(17 \%) \\
4242(54 \%) \\
576(7 \%) \\
774(10 \%)\end{array}$ & $\begin{array}{c}1 \text { (Reference) } \\
0.75(0.35,1.57) \\
0.85(0.45,1.63) \\
1.75(0.60,5.05)\end{array}$ & $\begin{array}{c}1 \text { (Reference) } \\
0.78(0.43,1.40) \\
0.65(0.39,1.07) \\
0.72(0.34,1.52)\end{array}$ & $\begin{array}{c}1 \text { (Reference) } \\
1.04(0.64,1.70) \\
0.76(0.49,1.18) \\
0.41(0.19,0.89)\end{array}$ \\
\hline \multicolumn{7}{|l|}{ Differentiation } \\
\hline $\begin{array}{l}\text { Well } \\
\text { Moderate } \\
\text { Poor } \\
\text { Missing/other }\end{array}$ & $\begin{array}{l}22(15 \%) \\
97(66 \%) \\
16(11 \%) \\
11(8 \%)\end{array}$ & $\begin{array}{c}21(9 \%) \\
127(52 \%) \\
55(22 \%) \\
42(17 \%)\end{array}$ & $\begin{array}{c}633(8 \%) \\
4712(60 \%) \\
1149(15 \%) \\
1384(18 \%)\end{array}$ & $\begin{array}{c}1 \text { (Reference) } \\
0.88(0.45,1.75) \\
0.33(0.14,0.78)\end{array}$ & $\begin{array}{c}1 \text { (Reference) } \\
0.62(0.38,1.02) \\
0.41(0.21,0.82)\end{array}$ & $\begin{array}{c}1 \text { (Reference) } \\
0.70(0.43,1.15) \\
1.25(0.73,2.14)\end{array}$ \\
\hline \multicolumn{7}{|l|}{ Histology } \\
\hline $\begin{array}{l}\text { Adenocarcinoma } \\
\text { Mucinous } \\
\text { Signet ring } \\
\text { Missing/other }\end{array}$ & $\begin{array}{c}132(90 \%) \\
11(8 \%) \\
1(1 \%) \\
2(1 \%)\end{array}$ & $\begin{array}{c}191(78 \%) \\
41(17 \%) \\
4(2 \%) \\
9(4 \%)\end{array}$ & $\begin{array}{c}6771(86 \%) \\
856(11 \%) \\
79(1 \%) \\
172(2 \%)\end{array}$ & $\begin{array}{c}1 \text { (Reference) } \\
0.39(0.19,0.80) \\
0.38(0.04,3.44)\end{array}$ & $\begin{array}{c}1 \text { (Reference) } \\
0.68(0.36,1.27) \\
0.68(0.09,4.96)\end{array}$ & $\begin{array}{c}1 \text { (Reference) } \\
1.72(1.21,2.45) \\
1.79(0.64,5.07)\end{array}$ \\
\hline \multicolumn{7}{|c|}{ Additional features (yes/no) $\left(\%\right.$ yes) ${ }^{b}$} \\
\hline $\begin{array}{l}\text { Peritumoural lymphocytes } \\
\text { Crohn's-like lymphocytes } \\
\text { Tumour-infiltrating } \\
\text { lymphocytes } \\
\text { Venous invasion }\end{array}$ & $\begin{array}{l}23 / 57(28 \%) \\
14 / 60(19 \%) \\
20 / 65(24 \%) \\
16 / 79(11 \%)\end{array}$ & $\begin{array}{l}61 / 71(46 \%) \\
61 / 70(37 \%) \\
98 / 43(70 \%) \\
9 / 135(4 \%)\end{array}$ & $\begin{array}{l}954 / 1608(37 \%) \\
627 / 1843(25 \%) \\
704 / 1920(27 \%) \\
735 / 4027(9 \%)\end{array}$ & $\begin{array}{l}0.49(0.26,0.90) \\
0.27(0.14,0.54) \\
0.14(0.07,0.26) \\
3.21(1.35,7.65)\end{array}$ & $\begin{array}{l}0.75(0.45,1.25) \\
0.78(0.43,1.41) \\
0.89(0.53,1.50) \\
1.27(0.73,2.21)\end{array}$ & $\begin{array}{l}1.54(1.07,2.23) \\
2.84(1.97,4.10) \\
6.41(4.40,9.36) \\
0.40(0.20,0.79)\end{array}$ \\
\hline $\begin{array}{l}\text { Abbreviations: AC1 = Amsterd } \\
{ }^{\mathbf{a}} \text { All models are adjusted for a } \\
{ }^{\mathbf{b}} \text { These features were only coll }\end{array}$ & $\begin{array}{l}\text {; } F C C T X=F a \\
\text { sis, sex, and } \\
r \text { of six study }\end{array}$ & $\begin{array}{l}\text { Colorectal Ca } \\
\text { ite. Referenc } \\
\text { Mayo Clinic, }\end{array}$ & $\begin{array}{l}\text { X. } \\
\text { is those without } t \\
\text { ia, } U H \text {, and }(C O) \text {. }\end{array}$ & racteristic. & & \\
\hline
\end{tabular}

comparing case groups: FCCTX vs LS, FCCTX vs non-AC1, and LS $v s$ non-AC1. ORs were adjusted for age at diagnosis, sex, and study site. Smoking history (ever/never smoked $\geq 1$ cigarette a day for $\geq 3$ months) was based on the history 1 year preceding diagnosis. Age at diagnosis and pre-diagnostic body mass index (BMI) were included in models as continuous variables. All other covariates were binary. Complete-cases analyses were conducted for all variables, with the exception of the histopathologic variables, which include those with missing and unknown as a separate category. Duplicates were removed for the limited number of participants $(n=307 ; 3.6 \%)$ who contributed more than one tumour sample. Analyses were performed using SAS 9.3 (Cary, NC, USA) and R 3.0.0 (Vienna, Austria). Reported $P$-values are two-sided; $P \leq 0.05$ was considered statistically significant.

\section{RESULTS}

FCCTX cases were slightly older at diagnosis than LS (mean 53.3 vs 50.5 years Table 1). By definition, all FCCTX and LS families met AC-1. In comparison, of the 9603 individuals who were classified as non-AC1, 33\% were diagnosed before age $50,5 \%$ had two or more first-degree relatives with CRC ( $13 \%$ had one first-degree relative), and $15 \%$ had MSI-high tumours.

The self-reported proportion of ever smokers was similar across the three groups, but FCCTX had the lowest prevalence of current smokers $(P=0.03$ and 0.12 compared with LS and non-AC1, respectively). A higher proportion of FCCTX $v s$ LS reported being former smokers. BMI and the prevalence of diabetes, hyperlipidemia, aspirin/NSAID and other medication usage, and gynaecologic history elements did not vary significantly between groups.

FCCTX CRCs were less often located in proximal subsites than LS (caecal, ascending, or transverse colon; all $P<0.001$, Table 2); no subsite difference was observed for FCCTX vs non-AC1 tumours. Overall, the LS group had the lowest proportion of T4 tumours, but a statistically significant difference was observed only when comparing LS and non-AC1 CRCs. Nodal N-stage could not be reliably assessed owing to the variability in missing data between sites (data not shown).

FCCTX CRCs were more commonly poorly differentiated compared with LS/non-AC1 tumours, and were less often mucinous than LS tumours. FCCTX tumours had a smaller proportion of peritumoural lymphocytes, Crohn's-like reaction, 
and TIL than LS CRCs, but there was no difference compared with non-AC1 tumours. Venous invasion was most commonly seen in FCCTX tumours.

\section{DISCUSSION}

This study evaluated epidemiologic and clinicopathologic data across FCCTX, LS, and non-AC1 cases of CRC. A statistically significant difference across these groups was noted for smoking history, whereas no differences were observed in co-morbidities, medication use, or gynaecologic history elements. Classic histopathologic features of LS CRCs were much less commonly observed in FCCTX CRCs. There were no clear distinguishing features for FCCTX vs non-AC1 tumours.

Comparison of FCCTX and LS. Individuals classified as FCCTX were less likely to be current smokers. Tobacco use is associated with a higher incidence of colorectal adenoma and invasive CRC in both the general population and in LS (Watson et al, 2004; Botteri et al, 2008; Pande et al, 2010). The difference in CRC prevalence between FCCTX and LS may be partially mediated by differences in tobacco use habits, although we cannot rule out that smoking has less effect in FCCTX than in LS.

In this comprehensive pathologic analysis, we confirmed the previously-reported left- $v$ s right-sided predominance of FCCTX $v s$ LS by subsite (Llor et al, 2005; Mueller-Koch et al, 2005; Valle et al, 2007). In the present analysis, there were also a greater proportion of large (T4) primary FCCTX tumours compared with LS CRCs. On histologic review, the mucinous histology, poor differentiation, and TIL features reported as characteristic of LS tumours (Jenkins et al, 2007) were not common in FCCTX CRCs. Prior studies have analysed some of these features, but with inconsistent results (Llor et al, 2005; Valle et al, 2007; Chen et al, 2008; Klarskov et al, 2011; Koh et al, 2011; Klarskov et al, 2012). FCCTX CRCs in our analysis also had a lower proportion for peritumoural lymphocytes and Crohn's-like reaction, but a significantly higher proportion had venous invasion relative to that observed in LS CRCs.

Comparison of FCCTX and non-AC1. Epidemiologic factors did not distinguish FCCTX and non-AC1 cases. FCCTX tumours had significantly lower frequency of poor differentiation than non-AC1 CRCs and a trend toward a higher proportion with venous invasion. Tumour subsite, T-stage, and tumoural lymphocytes were not observed to differ between FCCTX and non-AC1 tumours.

Strengths and limitations. This analysis benefits from a large, international cohort of patients with standardised data collection, providing the opportunity to compare FCCTX, LS, and non-AC1 CRCs in the first epidemiologic and in-depth clinicopathologic analysis. The epidemiologic features were assessed by a single baseline survey, as it is difficult to longitudinally evaluate any changes in these factors in such rare syndromes. To keep this analysis meaningful, we selected a classification based on the current information readily available to clinicians, namely personal and family history (the Amsterdam Criteria) and standard tumour analysis (MSI and/or MMR IHC). The non-AC1 cohort contains a mixture of sporadic MSI (typically due to MLH1 promoter hypermethylation and associated sporadic BRAF mutations (Lynch et al, 2007)) and non-MSI cases. CRC is increasingly being recognised as genetically and epigenetically heterogeneous (Marisa et al, 2013), making selection of a true comparison group difficult. FCCTX is likely also genetically heterogeneous and would benefit from in-depth molecular characterisation (Abdel-Rahman et al, 2005; Sanchez-de-Abajo et al, 2007; Goel et al, 2010). It should also be noted that it is possible, given the multiple statistical comparisons performed in this analysis, that the noted associations could be chance findings. Thus, independent validation is needed.

\section{CONCLUSIONS}

This study compared FCCTX, LS, and non-AC1 CRC cases. FCCTX were less likely to be current tobacco users; other exposures were similar between these groups. Subsite analysis confirms the distal colonic predominance of FCCTX vs LS CRCs. Histopathologically, mucinous histology, poor differentiation, and TIL were strongly associated with LS, rather than FCCTX or non$\mathrm{AC} 1$, tumours, whereas venous invasion was more commonly seen in FCCTX. Additional molecular analysis may eventually explain the observed histopathologic differences between FCCTX and LS tumours.

\section{ACKNOWLEDGEMENTS}

This work was supported by the National Cancer Institute (NCI), National Institutes of Health (NIH), under RFA CA-95-011 and through cooperative agreements with the members of the CCFR and principal investigators. The NCI and CCFR had no role in the design and conduct of the study; in the collection, analysis, and interpretation of the data; or in the preparation, review, or approval of the manuscript.

\section{CONFLICT OF INTEREST}

The authors declare no conflict of interest.

\section{DISCLAIMER}

The content of this article does not necessarily reflect the views or policies of the NCI or any of the collaborating centres in the Cooperative Family Registries, nor does mention of trade names, commercial products, or organisations imply endorsement by the US government or the Cooperative Family Registry. Collaborating centres include the Australian Colon Cancer Family Registry (U01 CA097735), the USC Familial Colorectal Neoplasia Collaborative Group (U01 CA074799), Mayo Clinic Cooperative Family Registry for Colon Cancer Studies (U01 CA074800), Ontario Registry for Studies of Familial Colorectal Cancer (U01 CA074783), Seattle Colon Cancer Family Registry (U01 CA074794), and University of Hawaii Colon Cancer Family Registry (U01 CA074806). Additional funding sources include: NIH T32-CA009515 (SS), T32-CA009168 (MNP), K05 CA152715 (PAN), KL2 TR000421 (ABH), and P30CA15704 (WMG).

\section{REFERENCES}

Abdel-Rahman WM, Ollikainen M, Kariola R, Jarvinen HJ, Mecklin JP, Nystrom-Lahti M, Knuutila S, Peltomaki P (2005) Comprehensive characterization of HNPCC-related colorectal cancers reveals striking molecular features in families with no germline mismatch repair gene mutations. Oncogene 24(9): 1542-1551.

Botteri E, Iodice S, Bagnardi V, Raimondi S, Lowenfels AB, Maisonneuve P (2008) Smoking and colorectal cancer: a meta-analysis. JAMA 300(23): 2765-2778.

Chen JR, Chiang JM, Changchien CR, Chen JS, Tang RP, Wang JY (2008) Mismatch repair protein expression in Amsterdam II criteria-positive patients in Taiwan. Br J Surg 95(1): 102-110.

Dove-Edwin I, de Jong AE, Adams J, Mesher D, Lipton L, Sasieni P, Vasen HF, Thomas HJ (2006) Prospective results of surveillance colonoscopy in dominant familial colorectal cancer with and without Lynch syndrome. Gastroenterology 130(7): 1995-2000. 
Goel A, Xicola RM, Nguyen TP, Doyle BJ, Sohn VR, Bandipalliam P, Rozek LS, Reyes J, Cordero C, Balaguer F, Castells A, Jover R, Andreu M, Syngal S, Boland CR, Llor X (2010) Aberrant DNA methylation in hereditary nonpolyposis colorectal cancer without mismatch repair deficiency. Gastroenterology 138(5): 1854-1862.

Jenkins MA, Hayashi S, O’Shea AM, Burgart LJ, Smyrk TC, Shimizu D, Waring PM, Ruszkiewicz AR, Pollett AF, Redston M, Barker MA, Baron JA, Casey GR, Dowty JG, Giles GG, Limburg P, Newcomb P, Young JP, Walsh MD, Thibodeau SN, Lindor NM, Lemarchand L, Gallinger S, Haile RW, Potter JD, Hopper JL, Jass JR. Colon Cancer Family R (2007) Pathology features in Bethesda guidelines predict colorectal cancer microsatellite instability: a population-based study. Gastroenterology 133(1): 48-56.

Klarskov L, Holck S, Bernstein I, Nilbert M (2012) Hereditary colorectal cancer diagnostics: morphological features of familial colorectal cancer type X versus Lynch syndrome. J Clinl Pathol 65(4): 352-356.

Klarskov L, Holck S, Bernstein I, Okkels H, Rambech E, Baldetorp B, Nilbert M (2011) Challenges in the identification of MSH6-associated colorectal cancer: rectal location, less typical histology, and a subset with retained mismatch repair function. Am J Surg Pathol 35(9): 1391-1399.

Koh PK, Kalady M, Skacel M, Fay S, McGannon E, Shenal J, Arroyo L, Toderick K, Church J (2011) Familial colorectal cancer type X: polyp burden and cancer risk stratification via a family history score. ANZ J Surg 81(7-8): 537-542.

Lindor NM, Rabe K, Petersen GM, Haile R, Casey G, Baron J, Gallinger S, Bapat B, Aronson M, Hopper J, Jass J, LeMarchand L, Grove J, Potter J, Newcomb P, Terdiman JP, Conrad P, Moslein G, Goldberg R, Ziogas A, Anton-Culver H, de Andrade M, Siegmund K, Thibodeau SN, Boardman LA, Seminara D (2005) Lower cancer incidence in Amsterdam-I criteria families without mismatch repair deficiency: familial colorectal cancer type X. JAMA 293(16): 1979-1985.

Llor X, Pons E, Xicola RM, Castells A, Alenda C, Pinol V, Andreu M, Castellvi-Bel S, Paya A, Jover R, Bessa X, Giros A, Roca A, Gassull MA. Gastrointestinal Oncology Group of the Spanish Gastroenterological A (2005) Differential features of colorectal cancers fulfilling Amsterdam criteria without involvement of the mutator pathway. Clin Cancer Res 11(20): 7304-7310.

Lynch HT, de la Chapelle A (2003) Hereditary colorectal cancer. The New England journal of medicine 348(10): 919-932.

Lynch HT, Lynch JF, Lynch PM (2007) Toward a consensus in molecular diagnosis of hereditary nonpolyposis colorectal cancer (Lynch syndrome). J Natl Cancer Inst 99(4): 261-263.

Marisa L, de Reynies A, Duval A, Selves J, Gaub MP, Vescovo L, Etienne-Grimaldi MC, Schiappa R, Guenot D, Ayadi M, Kirzin S, Chazal M, Flejou JF, Benchimol D, Berger A, Lagarde A, Pencreach E, Piard F, Elias D, Parc Y, Olschwang S, Milano G, Laurent-Puig P, Boige V (2013) Gene expression classification of colon cancer into molecular subtypes: characterization, validation, and prognostic value. PLoS Med 10(5): e1001453.

Mueller-Koch Y, Vogelsang H, Kopp R, Lohse P, Keller G, Aust D, Muders M, Gross M, Daum J, Schiemann U, Grabowski M, Scholz M, Kerker B, Becker I, Henke G, Holinski-Feder E (2005) Hereditary non-polyposis colorectal cancer: clinical and molecular evidence for a new entity of hereditary colorectal cancer. Gut 54(12): 1733-1740.

Newcomb PA, Baron J, Cotterchio M, Gallinger S, Grove J, Haile R, Hall D, Hopper JL, Jass J, Le Marchand L, Limburg P, Lindor N, Potter JD, Templeton AS, Thibodeau S, Seminara D. Colon Cancer Family R (2007) Colon Cancer Family Registry: an international resource for studies of the genetic epidemiology of colon cancer. Cancer Epidemiol Biomarkers Prev 16(11): 2331-2343.

Pande M, Lynch PM, Hopper JL, Jenkins MA, Gallinger S, Haile RW, LeMarchand L, Lindor NM, Campbell PT, Newcomb PA, Potter JD, Baron JA, Frazier ML, Amos CI (2010) Smoking and colorectal cancer in Lynch syndrome: results from the Colon Cancer Family Registry and the University of Texas M.D. Anderson Cancer Center. Clin Cancer Res 16(4): 1331-1339.

Renkonen E, Zhang Y, Lohi H, Salovaara R, Abdel-Rahman WM, Nilbert M, Aittomaki K, Jarvinen HJ, Mecklin JP, Lindblom A, Peltomaki P (2003) Altered expression of MLH1, MSH2, and MSH6 in predisposition to hereditary nonpolyposis colorectal cancer. J Clin Oncol 21(19): 3629-3637.

Sanchez-de-Abajo A, de la Hoya M, van Puijenbroek M, Tosar A, Lopez-Asenjo JA, Diaz-Rubio E, Morreau H, Caldes T (2007) Molecular analysis of colorectal cancer tumors from patients with mismatch repair proficient hereditary nonpolyposis colorectal cancer suggests novel carcinogenic pathways. Clin Cancer Res 13(19): 5729-5735.

Schiemann U, Muller-Koch Y, Gross M, Daum J, Lohse P, Baretton G, Muders M, Mussack T, Kopp R, Holinski-Feder E (2004) Extended microsatellite analysis in microsatellite stable, MSH2 and MLH1 mutation-negative HNPCC patients: genetic reclassification and correlation with clinical features. Digestion 69(3): 166-176.

Valle L, Perea J, Carbonell P, Fernandez V, Dotor AM, Benitez J, Urioste M (2007) Clinicopathologic and pedigree differences in amsterdam I-positive hereditary nonpolyposis colorectal cancer families according to tumor microsatellite instability status. J Clin Oncol 25(7): 781-786.

Vasen HF, Mecklin JP, Khan PM, Lynch HT (1991) The International Collaborative Group on Hereditary Non-Polyposis Colorectal Cancer (ICG-HNPCC). Dis Colon Rectum 34(5): 424-425.

Watson P, Ashwathnarayan R, Lynch HT, Roy HK (2004) Tobacco use and increased colorectal cancer risk in patients with hereditary nonpolyposis colorectal cancer (Lynch syndrome). Arch Intern Med 164(22): 2429-2431.

Woods MO, Hyde AJ, Curtis FK, Stuckless S, Green JS, Pollett AF, Robb JD, Green RC, Croitoru ME, Careen A, Chaulk JA, Jegathesan J, McLaughlin JR, Gallinger SS, Younghusband HB, Bapat BV, Parfrey PS (2005) High frequency of hereditary colorectal cancer in Newfoundland likely involves novel susceptibility genes. Clin Cancer Res 11(19 Pt 1): 6853-6861.

This work is published under the standard license to publish agreement. After 12 months the work will become freely available and the license terms will switch to a Creative Commons AttributionNonCommercial-Share Alike 3.0 Unported License.

Supplementary Information accompanies this paper on British Journal of Cancer website (http://www.nature.com/bjc) 